\title{
WINE TRACEABILITY AND AUTHENTICITY: APPROACHES FOR GEOGRAPHICAL ORIGIN, VARIETY AND VINTAGE ASSESSMENT
}

\section{RASTREABILIDADE E AUTENTICIDADE DO VINHO: ABORDAGENS PARA A AVALIAÇÃO DA ORIGEM GEOGRÁFICA, CASTA E ANO DE VINDIMA}

\author{
Andrea Zava ${ }^{1}$, Pedro J. Sebastião ${ }^{2,3}$, Sofia Catarino ${ }^{1,2^{*}}$ \\ ${ }^{1}$ LEAF_-Linking Landscape, Environment, Agriculture and Food, Instituto Superior de Agronomia, Universidade de Lisboa, Tapada da Ajuda, \\ 1349-017 Lisboa, Portugal. \\ ${ }^{2}$ CEFEMA — Center of Physics and Engineering of Advanced Materials, Instituto Superior Técnico, Universidade de Lisboa, Av. Rovisco Pais, 1 , \\ 1049-001 Lisboa, Portugal. \\ ${ }^{3}$ Department of Physics, Instituto Superior Técnico, Universidade de Lisboa, Av. Rovisco Pais, 1049-001 Lisboa, Portugal.
}

* Corresponding author: Tel.: +351 213653438 , e-mail: sofiacatarino@isa.ulisboa.pt

(Received 29.06.2020. Accepted 02.10.2020)

\section{SUMMARY}

The aim of this work is to identify and discuss physicochemical wine characteristics, to provide to some extent a link to the vintage, variety, and/or geographical origin. Bibliographic datasets were attempted to provide the main information for topic comprehension, identifying the sources of wine compositional variability and how these can be expressed in terms of the belonging categories. Since all the environmental and technological conditions which vineyard and wine are subjected are rarely known, different sources were inspected. Great importance was given to the study of isotopic composition because of its importance in food frauds detection history. The interaction of the plant genotype with the environmental conditions of the vintage is the main responsible for the wines organic and inorganic fraction variability in terms of both total and relative content. This phenotypical expression, together with human and abiotic variability sources, has been examined since it contains to some extent the information for the discrimination of wines according to their category. Recently, new proton nuclear magnetic resonance $\left({ }^{1} \mathrm{H}\right.$ NMR) spectroscopy techniques have been under study and, used concurrently to chemometric data management procedures, showed to be an interesting and promising tool for wine characterization according to both vintage and variety.

\section{RESUMO}

Este trabalho de revisão bibliográfica tem por objectivo a identificação e discussão de características físico-químicas do vinho que permitam o estabelecimento de uma relação com o ano de vindima, casta e/ou origem geográfica. Apresenta-se a informação necessária para a compreensão do tema, com destaque para a inspecção das diferentes fontes de variabilidade composicional do vinho e de que modo estas podem ser expressas em termos de categorias de classificação. É dada especial atenção ao estudo da composição isotópica devido à sua importância no que respeita à detecção de fraudes em alimentos. A interacção do genótipo da planta com as condições ambientais do ciclo de produção é a principal responsável pela variabilidade da composição orgânica e inorgânica, em termos de concentração total e relativa. Recentemente, novas técnicas de espectroscopia de ressonância magnética nuclear de protões $\left({ }^{1} \mathrm{H}\right.$ NMR) têm sido estudadas e, usadas concomitantemente aos procedimentos de gestão de dados quimiométricos, demonstrando ser uma ferramenta interessante e promissora para a caracterização do vinho de acordo com o ano de vindima e casta.

Key words: Wine, authenticity, isotopes, NMR, biotic/abiotic fractionation.

Palavras-chave: Vinho, autenticidade, isótopos, RMN, fracionamento biótico/abiótico.

\section{INTRODUCTION}

Over the last decades, there has been an increase in attention to the quality and composition of food products; this includes the assessment of alimentary characteristics, such as nutritional parameters, shelf life and healthiness. Together with the public interest, the producers themselves start to understand the economic benefits linked the authenticity of some specific products, but the increasing in number of economically motivated adulterations (EMA), also known as food frauds, can have strong impacts on human health and/or on the specific markets (Everstine et al., 2013). According to the United 
States Food and Drug Administration (FDA) an aliment can be defined as adulterated when "any valuable constituent has been in whole or in part omitted (...) or if any substance has been substituted wholly or in part (...) or if any substance has been added thereto (...) so as to increase its bulk or weight, or reduce its quality or strength, or make it appear better or greater value than it is" (U.S. Food and Drugs Administration, 2010). To increase the traceability and to grant the particular food and beverage characteristics, the single Countries of the European Union developed restrictions and regulations per each specific sector through Protected Designation of Origin (PDO): e.g. Denominação de Origem Controlada (DOC) in Portugal, Denominazione di Origine Controllata and Denominazione di Origine Controllata e Garantita (DOC and DOCG) in Italy, Appellation d'Origine Controllée (AOC) in France and Switzerland, and Denominación de Origen (DO) in Spain (Meloni and Swinnen, 2013).

The interest in authenticity assessment as a research field has increased over the last 25 years, and wine takes second place in terms of number of publications, beaten only by grouped cereals, fruit and vegetables (Danezis et al., 2016). The high added value of some wine Designations of Origin induces the undesirable effect of making the use of notcertified grapes and wines economically interesting, to mislead consumers, marketing products under fake mentions. It is not rare to read about this type of fraudulent actions: for instance, during 2009 about 2 million litres of high quality level wine (Brunello di Montalcino DOCG) have been downgraded in Tuscany (IT) due to blending with non-authorized grapes (Asimov, 2009). A similar case was found in France, where a producer was discovered relabelling imported wines under the Bordeaux "Appellation" (Paris, 2002). Even if these types of frauds do not directly affect human health, the negative impact of single cases on consumer perception could cause huge economic repercussions on the producing territories (Holmberg, 2010). Together with mislabelling, the main fraud case involve chaptalisation, or the addition of exogenous sugar with the intent of increasing the alcoholic potential of wines, and the dilution with water to both decrease the alcoholic potential and increase the production. The last two fraud examples are better defined by law as adulterations.

To give an idea about the number of fraudulent wines on market, in 2002 the Landesuntersuchungsamt (LUA) started an investigation on more than 6000 Germans and non-German wine labels. The investigation continued until 2008 and around 4\% of wines were found to contain illegally added water or other substances, or to be produced starting from notauthorized grapes (Holmberg, 2010). The need for well-developed and discussed analytical procedures to detect such adulterations and consumer frauds is obvious and essential to maintain or even increase purchaser confidence in PDO. In the following section, an introduction on fraud detection through the isotopic ratio analysis is given, both to chronologically follow the research, and because of the current interest in this topic. After that, the main wine variability in terms of chemical composition will be briefly treated in order to find possible information linkable to grape variety, geographical origin and/or vintage. These are to some extent coded into analytical patterns which can be extracted through the application of spectral analysis: the most recent developments in ${ }^{1} \mathrm{H}$ NMR spectroscopy (Godelmann et al., 2013; Godelmann et al., 2016) are example on how increasing the investigation of this analytical tool is of extreme interest.

\section{EVALUATING WINE AUTHENTICITY: HOW TO STUDY ISOTOPIC PROFILING HELPS FRAUD AND MISLABELLING DETECTION}

In the 1982 the physical organic chemistry laboratory of the Nantes Science Faculty started developing an analytical protocol to determine the origin of natural alcohols by the relative deuterium (D) content (Martin et al., 1982); eight years later, it became the first official method to be adopted by the European Commission (EC) (Christoph et al., 2015). The hydrogen $(\mathrm{H})$, oxygen $(\mathrm{O})$ and carbon $(\mathrm{C})$ isotope fractionation processes have been under studies for years: the goal is to find a reasonable pattern to recognize wine provenance in terms of geographical origin, vintage, variety and adopted technologies. The determination of the deuterium relative intermolecular isotope concentration is called sitespecific natural isotopic fractionation-nuclear magnetic resonance (SNIF-NMR) analysis and it represents only one example of the stable isotope ratio analysis (SIRA). In fact, more recently the strontium ( $\mathrm{Sr}$ ) isotopic ratio has been taken into consideration as a suitable marker in wine geographical origin characterization (Martins et al., 2014; Kaya et al., 2017). Nowadays, also due to innovation in instrumental and analytical strategies, new approaches are under study such as the rare-earth elements (REE) profile (Catarino et al., 2011; Catarino et al., 2018) and the ${ }^{1} \mathrm{H}$ NMR spectroscopy (Godelmann et al., 2013; Godelmann et al., 2016).

\section{The isotopic ratio}

The ones shown in Table I are standard IUPAC reference values (Meija et al., 2016); the indicated 
ranges derive from several investigation of different types of samples, from food to inorganic matter. A standard value called Natural Abundance (Equation 1) (NA) is defined, which represents the relationship between environmental concentration of the given isotope in relation to its total abundance (Schmidt, 2003).

$$
\mathrm{NA}(\%)=\frac{{ }^{\mathrm{A}} \mathrm{X}_{\mathrm{j}}}{\sum_{\mathrm{j}=1}^{\mathrm{n}}\left[{ }^{\mathrm{A}} \mathrm{X}_{\mathrm{j}}\right]} \cdot 100
$$

When classifying the isotopic content of specific samples, it is used to describe the relative deviation $(\delta)$ from international standard (Equation 2) (Christoph et al., 2015) through the relation (Schmidt, 2003):

$$
\begin{aligned}
& \mathrm{R}=\frac{{ }^{\mathrm{m}} \mathrm{X}}{{ }^{\mathrm{n}} \mathrm{X}} \\
& \delta(\% \mathrm{o})=\frac{\mathrm{R}_{\text {Sample }}-\mathrm{R}_{\text {Standard }}}{\mathrm{R}_{\text {Standard }}} \cdot 1000=\left(\frac{\mathrm{R}_{\text {Sample }}}{\mathrm{R}_{\text {Standard }}}-1\right) \cdot 1000 \quad \text { Eq. } 2
\end{aligned}
$$

in which $\mathrm{m}$ is the mass number of the heaviest isotope and $\mathrm{n}$ is the mass of another isotope of the $\mathrm{X}$ element, respectively, considered in nature or into a sample under analysis.

Since these numbers result generally very small (e.g. the deuterium $\mathrm{R}_{\text {Standard }}$ is equal to $1.557610^{-4}$ ), it is preferable to work with $\delta \mathrm{D}$ standard values which, as will be seen, must be defined for each type of sample. Both $\delta \mathrm{D}$ and $\delta^{18} \mathrm{O}$ are evaluated in terms of deviation from the Vienna Standard Mean Ocean Water (VSMOW) values (Craig, 1961; Christoph et al., 2015).

Table I

Isotopes of interest for wine traceability and authenticity assessment: atomic and mass number and their abundance in nature (Meija et al., 2016; Haynes et al., 2017)

\begin{tabular}{|c|c|c|c|c|}
\hline Isotope & Atomic Number (Z) & Mass Number (A) & $\begin{array}{c}\text { Range of Natural } \\
\text { Variation (\%) }\end{array}$ & $\begin{array}{l}\text { Representative Isotope } \\
\text { Composition (\%) }\end{array}$ \\
\hline${ }^{1} \mathrm{H}$ & 1 & 1 & {$[99.972,99.999]$} & 99.9885 \\
\hline${ }^{2} \mathrm{H}$ & 1 & 2 & {$[0.001,0.028]$} & 0.0115 \\
\hline${ }^{10} \mathrm{~B}$ & 5 & 10 & {$[18.9,20.4]$} & 19.82 \\
\hline${ }^{11} \mathrm{~B}$ & 5 & 11 & {$[79.6,81.1]$} & 80.18 \\
\hline${ }^{12} \mathrm{C}$ & 6 & 12 & {$[98.84,99.04]$} & 98.93 \\
\hline${ }^{13} \mathrm{C}$ & 6 & 13 & {$[0.96,1.16]$} & 1.07 \\
\hline${ }^{16} \mathrm{O}$ & 8 & 16 & {$[99.738,99.776]$} & 99.757 \\
\hline${ }^{18} \mathrm{O}$ & 8 & 18 & {$[0.187,0.222]$} & 0.205 \\
\hline${ }^{86} \mathrm{Sr}$ & 38 & 86 & {$[9.75,9.99]$} & 9.86 \\
\hline${ }^{87} \mathrm{Sr}$ & 38 & 87 & {$[6.94,7.14]$} & 7.00 \\
\hline${ }^{204} \mathrm{~Pb}$ & 82 & 204 & {$[1.04,1.65]$} & 1.04 \\
\hline${ }^{206} \mathrm{~Pb}$ & 82 & 206 & {$[20.84,27.48]$} & 24.1 \\
\hline${ }^{207} \mathrm{~Pb}$ & 82 & 207 & {$[17.62,23.65]$} & 22.1 \\
\hline${ }^{208} \mathrm{~Pb}$ & 82 & 208 & {$[51.28,56.21]$} & 52.4 \\
\hline
\end{tabular}

Isótopos de interesse para rastreabilidade e avaliação da autenticidade do vinho: número atómico, número de massa e abundância na natureza (Meija et al., 2016; Haynes et al., 2017)

\section{Stable isotope fractionation process}

The main isotopic abundance ratios considered, or still in course of study, in the anti-fraud field are ${ }^{2} \mathrm{H} /{ }^{1} \mathrm{H}$ (also referred to as $\left.\mathrm{D} / \mathrm{H}\right),{ }^{13} \mathrm{C} /{ }^{12} \mathrm{C},{ }^{18} \mathrm{O} /{ }^{16} \mathrm{O}$ and ${ }^{87} \mathrm{Sr} /{ }^{86} \mathrm{Sr}$. If these values were constant over the entire Earth's surface, and/or within each type of matrix analysed, it would not be possible to use them as discriminating factors in attempts to distinguish between different samples. Luckily, in nature processes called stable isotope fractionation exist, which cause alteration in the distribution of isotopes both within the biomolecules and vegetable water (Christoph et al., 2015). It is possible to distinguish between two main sources of isotopic fractionation: biotic and abiotic. Analysing these phenomena in detail, it is possible to understand the sources of 
variability that can affect samples relating to specific categorical variables (e.g. geographical origin).

\section{Abiotic fractionation}

The evapotranspiration activity is capable itself of altering the isotopic distribution $\left(\mathrm{D} / \mathrm{H}\right.$ and $\left.{ }^{18} \mathrm{O} /{ }^{16} \mathrm{O}\right)$ in vegetal water samples with respect to the values found in the soil (Dunbar, 1982); this has a direct effect on the content of the same isotopes within the juices, deriving from fruit and consequently in their fermented products (e.g. wine). The leaves accumulation of the ${ }^{18} \mathrm{O}$ isotope has been correlated to the combined effect of the increase in relative humidity and air temperature (Dongmann et al., 1974); the greater volatility of lighter and smaller atoms composing water molecules (Christoph et al., 2015) justifies the phenomenon. Consequently, disadvantageous conditions for stomatal transpiration and water evaporation cause an increase in the concentration of heavier isotopes: for instance, the higher volatility of lighter oxygen isotope leads the heavier isotope to concentrate in all water sources (Gill et al., 2007); a vintage and/or geographical origin effect follows, as can be studied through the difference between samples in $\delta$ (Equation 2) values (Bréas et al., 1994). The $\mathrm{D} / \mathrm{H}$ and ${ }^{18} \mathrm{O} /{ }^{16} \mathrm{O}$ ratios in water rainfall are not always the same; they vary according to (Craig, 1961; Christoph et al., 2015):

- Latitude and altitude - lower presence in heavier isotopes are shown at higher latitude due to greater precipitation rate;

- Continental effect - a decrease in the presence of heavy isotopes is shown to the extent that it moves away from cost areas;

- Temperature - induces a concentration effect due to greater volatility of lighter isotopes.

Therefore, both the $\mathrm{D} / \mathrm{H}$ and ${ }^{18} \mathrm{O} /{ }^{16} \mathrm{O}$ ratios code themselves information about sample geographical origin (Craig, 1961). In any case, it is important to pay attention to meteorological data in order to justify anomalies in the isotopic ratios of musts and wines: in case of rainfall during the last grape maturation phase, an important dilution effect on deuterium concentration was reported by Dunbar (1982).

\section{Biotic fractionation}

The isotopic concentration within plant products (e.g. wine) is not predetermined solely by their natural distribution, and therefore by abiotic fractionation, but also depends on interaction between plant and environment. Biotic fractionation refers to the physiological processes, including biosynthetic pathways, that cause an alteration of isotopic abundance within plant tissues and/or between plant and environment. According to Schmidt (2003), the redistribution processes are regulated by thermodynamic or enzymatic kinetics laws, which in turn represent the genotypic and phenotypic expression of plants (interaction between plant and environment). Therefore, $\mathrm{pH}$, temperature and metal ions concentration affect the fractionation intensity (O'Leary, 1978). In general, during the photosynthetic pathway plants discriminate in favour of lighter isotopes (Bender, 1971) even if C3 and C4 plants show different behaviour in this sense (Martin et al., 1991). The main difference in these two vegetal classes lies in the carbon dioxide fixation, and leads to different biotic fractionation intensity. The greater efficiency of the $\mathrm{C} 4$ pathway decreases the ${ }^{13} \mathrm{C} /{ }^{12} \mathrm{C}$ ratio in favour of higher ${ }^{13} \mathrm{C}$ concentration and, therefore, it is possible to distinguish the sugar origin, in terms of plant type (Martin et al., 1991). In addition, it has been observed a discrimination factor in the carbon dioxide diffusion into liquid phase (Farquhar et al., 1982), which varies in turn by the different plant reactions (stomatal conductance) under water stress condition (Tramontini et al., 2013). Other biological fractionation effects on carbon isotopic ratio were discussed by Tcherkez et al. (2011). Regarding the $\mathrm{D} / \mathrm{H}$ and ${ }^{18} \mathrm{O} /{ }^{16} \mathrm{O}$ values, no interesting biological fractionation have been reported at vegetal tissues level; the heavy isotope concentration is therefore related, as previously discussed, mainly to the evapotranspiration requirement and to the distribution in environmental water.

Finally, the variation of the isotope distribution can be studied as a global phenomenon (infra-molecular natural fractionation) or localized (site specific natural isotopic fractionation) (Christoph et al., 2015); the possibility of localizing within the biosynthetic and/or catalytic pathway the elements origin, more precisely the hydrogen isotopes that constitute specific ethanol chemical groups, led to the development of the first analytical method recognized by the European Union for must chaptalisation identification during legal disputes (Martin et al., 1983).

Isotopes as chemical markers for wine fraud assessment

The fermentation process does not seem to significantly affect the $\mathrm{D} / \mathrm{H}$ and ${ }^{18} \mathrm{O} /{ }^{16} \mathrm{O}$ ratios in preand post-fermentation samples. Equation 3 quantifies the changes in water hydrogen isotopic ratio.

$$
\Delta(\mathrm{D} / \mathrm{H})_{\mathrm{W}}^{\mathrm{QS}}=(\mathrm{D} / \mathrm{H})_{\mathrm{W}}^{\mathrm{Q}}-(\mathrm{D} / \mathrm{H})_{\mathrm{W}}^{\mathrm{S}}
$$

where $(\mathrm{D} / \mathrm{H}) \underset{\mathrm{W}}{\mathrm{S}}$ and $(\mathrm{D} / \mathrm{H})_{\mathrm{W}}^{\mathrm{Q}}$ are the water deuterium isotopic ratios before and after the fermentation, 
respectively; $(\mathrm{D} / \mathrm{H})_{\mathrm{W}}^{\mathrm{QS}}$ value was find to be directly correlated, through a first degree relation, with the must starting fermentable sugar content (Martin et al., 1991). On the contrary, the oxygen isotopes concentration does not seems to be directly affected by the yeasts activity during the fermentation.

As aforementioned, an analytical procedure was developed for specific site isotopic analysis which allows discriminating solutions depending on the glucides plant origin (C3 vs $\mathrm{C} 4$ plants). The technology is called SNIF-NMR $\left({ }^{2} \mathrm{H}\right.$ NMR) and, in some cases, its application on wine samples has made possible the identification of fraudulent chaptalisation. The discrimination is made according to the $(\mathrm{D} / \mathrm{H})_{\mathrm{I}}$ value (Table II), that is the site specific natural isotopic fractionation on the ethanol methyl group. Since the concentration of deuterium in wine samples is strongly influenced both by the area of origin and by the rainfall rate and timing (Craig, 1961; Dunbar, 1982), not all the results were clearly justifiable; in case of controversies, it is possible to implement the method investigating also the $\delta^{13} \mathrm{C}$ value. The ${ }^{18} \mathrm{O} /{ }^{16} \mathrm{O}$ ratio analysis in wine water (Dunbar, 1982) showed a direct correlation with the ${ }^{18} \mathrm{O}$ natural abundance. Since almost all the vine and wine oxygen derives from the natural water, absorbed through vine roots during productive cycle (Schmidt, 2003), the information carried by this atom could code for geographical origin and vintage (Bréas et al., 1994). There would seem to be no coded information by the isotopic carbon ratio (Bréas et al., 1994) since, even if used in archaeological studies to organic matter dating, the readings range of error is between 50 and 100 years (Diamond, 2005; Gill et al., 2007).

\section{Table III}

Isotopic ratio $(\mathrm{D} / \mathrm{H})$ in samples of ethanol obtained from the fermentation of various substrates (Martin et al., 1982).

Razão isotópica $(D / H)$ em amostras de etanol resultantes da fermentação de vários substratos (Martin et al., 1982)

\begin{tabular}{cccccccc}
\hline & Grape & Corn & Sugar Cane & Wheat & Potato & Sugar Beet & Apple \\
\hline$(\mathrm{D} / \mathrm{H})_{\mathrm{I}}$ & 102.2 & $111.6 \pm 2$ & $111.2 \pm 2.5$ & 103.5 & $97.3 \pm 4$ & $94.1 \pm 2$ & 100.9 \\
$(\mathrm{D} / \mathrm{H})_{\mathrm{II}}$ & 129.7 & $123.9 \pm 2$ & $127.8 \pm 2.5$ & 128.3 & $131.8 \pm 4$ & $128.0 \pm 2$ & 129.7
\end{tabular}

$(\mathrm{D} / \mathrm{H})_{\mathrm{I}}$ and $(\mathrm{D} / \mathrm{H})_{\mathrm{II}}$ identify the hydrogen isotopic ratios on the ethanol methyl and methylene groups, respectively. Values for grapes have been extrapolated from "Compendium of international methods of wine and must analysis" (O.I.V. 2019b). Not all the standard deviation data were available.

More recent studies have demonstrated the possibility to geolocate wine samples depending on their strontium isotopic abundance and strontium isotopic ratio $\left({ }^{87} \mathrm{Sr} /{ }^{86} \mathrm{Sr}\right)$; the naturally occurring isotopes of this element are four and their abundance is reported in Table I. The discrimination is possible due to fractionation phenomenon absence during radical absorption, xylem translocation and plant metabolism (Petrini et al., 2015). This, together with the fact that fractionation does not occur during strontium dissolution from the soil's mother rock (English et al., 2001), means that isotopic distribution within plant tissues it is not only representative of that diluted into the circulating solution (Petrini et al., 2015), but can be directly associated with the soil composition which it comes from (English et al., 2001). According to the same authors, the soil strontium composition does not depend solely on mother rock content but also on the rubidium $(\mathrm{Rb})$ concentration at its formation; in addition, in some areas, the atmospheric sand can give a contribution even four times greater in comparison to the last mentioned two. Therefore, the
$\mathrm{R}_{\text {Standard }}$ (Equation 2) must be continuously maintained up to date depending on local weather.

What does the ${ }^{87} \mathrm{Sr} /{ }^{86} \mathrm{Sr}$ relationship depend on and why is it a good indicator of geographical origin? The formation of strontium 87 isotope is a radioactive decay consequence of another element: rubidium. The speed at which occurs depends solely on the half-life of ${ }^{87} \mathrm{Rb}$ and consequently, both ${ }^{87} \mathrm{Rb} /{ }^{87} \mathrm{Sr}$ and ${ }^{87} \mathrm{Sr} /{ }^{86} \mathrm{Sr}$ values are proportional to the age of the rocks (Faure and Powell, 1972).

Some noteworthy developments showed how the strontium isotopic ratio to be a reliable tool for the traceability of Portuguese DO wines, where soils were developed on different geological formations (Martins et al., 2014). Since strontium is also able to replace calcium $(\mathrm{Ca})$ during igneous rocks formation while $\mathrm{Rb}$ replaces potassium $(\mathrm{K})$ in the silicate rocks (such as mica rock and potassium feldspar) formation (Faure and Powell, 1972), observing the distribution of such elements, together with the ${ }^{87} \mathrm{Rb} /{ }^{87} \mathrm{Sr}$ and ${ }^{87} \mathrm{Sr} /{ }^{86} \mathrm{Sr}$ ratios, could increase the chances of 
predicting the geographical origin of a wine sample. The National R\&D Institute for Cryogenics and Isotopic Technologies (ICSI) in Vilcea (RO) (Geană et al., 2017) has managed to classify, with $100 \%$ of success, the geographical origin of 21 red wines with denomination of origin (PDO) or geographical indication (GI). The developed method combines the $\mathrm{Sr}$ isotopic ratio together with $\mathrm{Ca} / \mathrm{Rb}$ value and other element concentration (aluminium, gallium, strontium). More recently, the lead $(\mathrm{Pb})$ isotopic ratios, namely ${ }^{204} \mathrm{~Pb} /{ }^{206} \mathrm{~Pb},{ }^{208} \mathrm{~Pb} /{ }^{206} \mathrm{~Pb}$ and ${ }^{207} \mathrm{~Pb} /{ }^{206} \mathrm{~Pb}$, demonstrated their utility in wine sample discrimination according to geographical origin in Romania (Bora et al., 2018). It must be stated that the isotopic composition in wine could be in some extent modified due to atmospheric lead released as a consequence of the use of leaded-gasoline (Medina et al., 2010); the heavy metal contamination problem is decreasing after the removal of this fuel type from the market, but the possibility of observing and increase due to contact with old equipment during the vinification still persists. Anyway, further investigation regarding the technological treatment effect on metals isotopic ratio has been carried out (Kaya et al., 2017; Moreira et al., 2017) confirming what was discovered before by Martins et al. (2014): depending on the vine-growing country, the strontium isotopic ratio can be used to geographically discriminate the wine producing area.

Finally, the research has demonstrated how inspecting the information coded in boron isotopic ratio $\left({ }^{11} \mathrm{~B} /{ }^{10} \mathrm{~B}\right)$ for wine geographical origin permits its discrimination, whether it is produced in different countries (Coetzee and Vanhaecke, 2005) or within the same borders (Vorster et al., 2010).

\section{Uncertainty sources}

As highlighted in the previous paragraphs, each isotopic ratio encodes one or more categorical variables; this means that variations in their values are to some extent a function of:

- Genotype or varietal phenotypic expression;

- Vintage;

- Geographical origin.

However, it is not possible to limit the observations to these parameters as they can be altered by unpredictable external factors; for example their variation during bottle ageing or as a consequence of direct contact with polluting material during processing, must still be evaluated. What would happen during a dry year to the ${ }^{18} \mathrm{O} /{ }^{16} \mathrm{O}$ values in case of irrigation? As for the ratio ${ }^{87} \mathrm{Sr} /{ }^{86} \mathrm{Sr}$, there may exist producing areas with common geological origin.
A solution comes from the possibility of inspecting multiple markers (Vorster et al., 2010): the capability of isotopic ratio to discriminate variety and vintage has been proven by Dinca et al. (2015) but, more information about weather trends is needed to discuss relations between sample discrimination and the date of rainfall events. If the goal is to combat mislabelling, it is necessary to increase the amount of information linkable to the categories listed above (Ogrinc et al., 2001). Many official analytical techniques to investigate the wine chemical composition are available (OIV, 2019a,b) but, since it is unthinkable to develop a model that includes them all, it is necessary to inspect the applicability of advanced spectroscopic analytical techniques, such as ${ }^{1} \mathrm{H}$ NMR, ultraviolet (UV), visible (Vis), near infrared (NIR), medium infrared (MIR) and/or Raman. Through the information amount increase, it would be possible to create a chemical fingerprint which, as it works for humans, would univocally code each wine. As shown by Geană et al. (2017), it is essential to determine where this information is coded to create models and, because of that, the combination of chemometrics, bioinformatic and geographical information system (GIS) data, is essential to integrate and translate analytical data (Danezis et al., 2016).

\section{WINE COMPOSITION AS AN INFORMATION SOURCE FOR ITS TRACEABILITY}

This section aims to provide a general overview of the wine chemical species of interest to underline possible sources of varietal, geographical origin and vintage information. The main division lies between inorganic and organic compounds.

\section{Mineral elements}

The main inorganic compound for concentration in wine is water which, as previously discussed, can convey interesting information regarding geographical origin and vintage if studied in terms of its isotopic ratios.

The interest in wine geographical origin assessment through the analysis of mineral elements is one of the main topics regarding foodstuff mislabelling: Geană et al. (2017) provided interesting observations about wine samples differentiation based on their elemental composition. In these terms, significant differences were found in the concentration of $\mathrm{Ca}$, gallium $(\mathrm{Ga})$, $\mathrm{Sr}$, aluminium ( $\mathrm{Al})$ and in the $\mathrm{Ca} / \mathrm{Sr}$ ratio according to different production areas; it means that these elements are to some extent predictive of wine geographical origin or, their variation could partially code for that. However, the possibility of observing changes in $\mathrm{Ca}, \mathrm{Al}$ and $\mathrm{Ga}$ profile between must and 
wine should be considered; during the vinification process, these elements are subject to fluctuations, the intensity of which is often unpredictable. The $\mathrm{Ca}$ concentration varies as a consequence of calcium tartrate insolubility and consequently, precipitation can occur during both vinification and wine storage; the other two are part of a larger group of contaminant elements, the concentration of which is strongly affected by sulfur dioxide addition and/or by oenological practices such as bentonite fining and filtration (Catarino et al., 2008a,b; Redan et al., 2019).

The absorption rate of different rootstocks still remains to be studied with respect to the individual elements, depending on the pluviometric trend and their assimilability. In addition, some technological treatment, as destemming (Cheng and Liang, 2012), could change the must/wine mineral composition; this has also been demonstrated after a 90 days ageing with staves trial (Kaya et al., 2017) for Sr, manganese $(\mathrm{Mg})$, nickel $(\mathrm{Ni})$, cobalt $(\mathrm{Co})$ and vanadium $(\mathrm{V})$ concentrations.

Before assessing the wine geographical origin through the realization of a multi-elemental

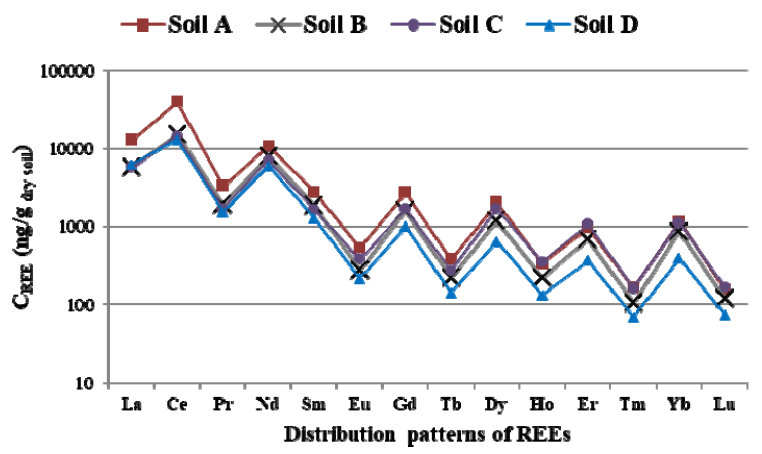

fingerprint the technological treatment effect on these latter should be considered: in fact, it is not possible in all the cases to assume the direct correlation between soil mineral composition and wine elemental profile (Catarino et al., 2008b). In addition, different behaviour in rootstocks capability to absorb water and minerals has been explained (Marguerit et al., 2012) to be to some extent, genetically controlled; this creates another variability source during wine sample classification and a varietal per vintage per rootstock interaction effect.

Despite these concerns, studies developed by Catarino et al. $(2011,2018)$ demonstrated that rareearth elements (REE) should be considered. Indeed, their chemical similarity and the absence in biotic and abiotic fractionation processes both during rootstock absorption and vinification make these elements interesting targets in wine geographical characterization. The soil/must/wine system change mainly affects the REE total content, as it is clear in Figure 1, where their concentration pattern seems in most cases to follow the soil one.

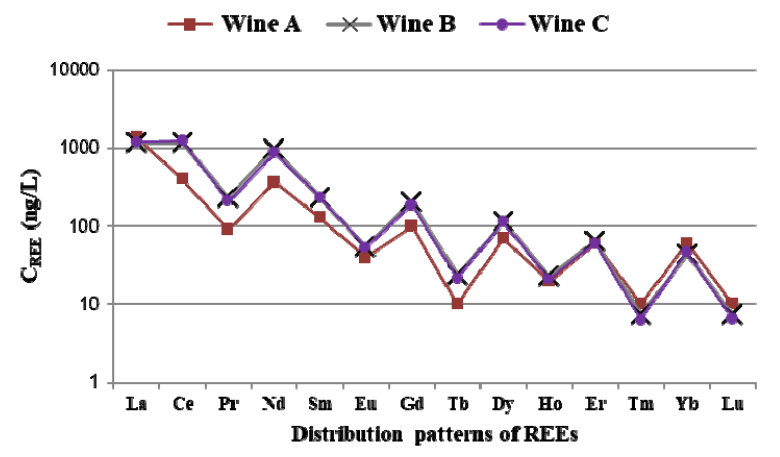

Figure 1. Chondrite normalised REE concentration $\left(\mathrm{C}_{\mathrm{REE}}\right)$ in soil (ng/g $\left.\mathrm{g}_{\text {dry soil }}\right)$ and corresponding wines (ng/L) (Catarino et al., 2011). Wine and related soils of origin are indicated using the same colours: wine A and wine B share the same pattern and "Denominação de Origem" (Óbidos D.O.P.). Soils A (Dão region) and B (Palmela region) show different composition patterns; wine A differs from wines B and C in the lighter REE concentrations.

Concentração de REE $\left(C_{R E E}\right)$ normalizada à condrite, no solo $\left(\mathrm{ng} / \mathrm{g}_{\text {solo seco }}\right)$ e nos vinhos $(\mathrm{ng} / \mathrm{L})$ correspondentes (Catarino et al., 2011). O vinho e os solos de origem relacionados são indicados usando as mesmas cores: o vinho A e o vinho B apresentam o mesmo padrão e a Denominação de Origem (Óbidos D.O.P.). Os solos A (região do Dão) e B (região de Palmela) apresentam diferentes padrões de composição; o vinho A difere dos vinhos $B$ e $C$ nas concentrações de REE mais leves.

It is interesting to emphasize the similarity between both the $\mathrm{B}$ and $\mathrm{C}$ patterns, whether soil or wine samples are considered, because these two productions arise from the same region (Óbidos). Though in this case the soil-wine composition correlation in terms of rare-earth elements is around 0.9 , it must be stressed that must and wine fining agents, as bentonite and other silica derivates, greatly influence on REE profiles (Rossano et al., 2007). These adjuvants are largely used to prevent protein 
casse in white wines and therefore, for now the applicability of this elemental fingerprinting should be limited on red wines.

\section{Organic compounds}

The main classes of wine organic molecules are organic acids, nitrogen compounds (amino acids, peptides and proteins), polyphenols, lipids, carbohydrates and aroma compounds (terpenes, norisoprenoids, thiols and esters). Many are the external and genetic influences on their concentration, absolute and/or relative; therefore, knowing the sources of this variability is essential to use them as chemical fingerprints (Danezis et al., 2016).

\section{Flavonoids}

The term flavonoid includes different phenolic categories, including flavan-3-ols, flavonols and anthocyanidin-3-o-glucosides. They can be found in the berry, mainly concentrated in the skin layers, and their variation mainly results from the genomeenvironment interaction. Expression changes of the biosynthetic pathway have been reported by Castellarin et al. (2007): following water stress situations, an increase in expression of genes which encode for enzymes asserting to the anthocyanin pathway is shown; according to the same author, as a result of a greater exposure of the berries to sunlight, an increase in the synthesis rate of flavonols, as biomolecules produced to protect from excessive UV irradiation, has been proven. The same direct radiation alters the anthocyanin profile (relative concentrations) which, although strongly dependent on variety (Jin et al., 2009), seems to be subject to changes during limiting environmental conditions. Flavonoids content in wine also depends on the technological treatment during grape processing, just think to the "blanc de noir" vinification, or the different maceration technologies (Sacchi et al., 2005) for white and red wines.

The term anthocyanins refers to a class of pigments found in many plant species within flowers, leaves and fruits. Their colours vary, depending on oxidation level and the $\mathrm{pH}$ of the medium within which they are dissolved, from red to blue (Ribéreau-Gayon et al., 2006a). The anthocyanins absolute and relative content in grapes depends mainly on cultivar (Bautista-Ortín et al., 2016), training system, maturity, and vintage (Canals et al., 2005).

Flavan-3-ols are another class of compounds present in grapes and wine; these are organized into polymeric structures of concatenated sub-units, called proanthocyanidins (PAC), the average degree of polymerization $(\mathrm{mDP})$ of which in berry skin cells varies as a result of environmental trends and vineyard management (Ribéreau-Gayon et al., 2006a). Flavanol polymerization with other molecules, including anthocyanins, gives rise to a large number of compounds, and the so occurring reaction products are mainly studied according to their size and colouring characteristics (RibéreauGayon et al., 2006a). In addition, from the polymerization between anthocyanins and carbonyl (e.g. ethanal, pyruvic acid) molecules, which originates mainly during fermentation, pyranoanthocyanins arise (Romano et al., 1994).

The possibility to technologically manage the flavonoid composition, in terms of concentration and $\mathrm{mDP}$, has been largely discussed and represents one of the main wine research topics (Canals et al., 2005; Bosso et al., 2009; Lerno et al., 2015; Smith et al., 2015). From the previous statements it is possible to gather useful information for sample characterisation according to variety, geographical origin and vintage: all these chemical classes are subject to variations which are strictly connected to vine genotype and phenotype expression depending on environmental conditions. This, together with vinification, vineyard management and wine ageing practices, explains itself the complexity in connecting categorical information to few chemical absolute and relative concentrations (Pereira et al., 2006). However, it is still noticeable how these data convey information that encode the environmental characteristics linked to vintage and wine production area.

\section{Non-flavonoids}

Non-flavonoids are divided into three main groups: hydrolysable tannins (gallotannins and ellagitannins), phenolic acids and stilbenes. The formers are polymers of different shapes and sizes which are extracted by the contact between wine and wood; they consist in gallic and ellagic acid subunits which concentration in wine mainly depends on the type of wood and contact time (Ribéreau-Gayon et al., 2006a). Non-flavonoids can therefore be considered as possible indicators of the process/refinement/ageing that characterise certain denominations more than others. Phenolic acids, on the other hand, are highly concentrated within the berry. These are mainly present in the form of hydroxycinnamoyl tartaric acids (HCTA), even though during vinification they are also released through the hydrolysis of tartaric acid. Coumaric, caffeic, ferulic and gallic acids are the ones known until now; their concentration seems to be affected by varietal components but not by weather changes (Ferrandino et al., 2012; Šuklje et al., 2012). Finally, stilbenes are a very important class for the food 
industry as they are designed and used as food additives for their high antioxidant activity. Their concentration may vary depending on the weather (vintage), altitude, but are also strongly influenced by the genetic (varietal) component (Bavaresco et al., 2007).

\section{Organic acids}

The main organic acids in wine generally come from four sources: grapes, yeasts, lactic and/or acetic bacteria physiological activity and intentionally added (Ribéreau-Gayon et al., 2006b). This discussion has little to do with the addition of exogenous acids; however, it is important to be aware about all treatments to which wine has been subject, since the use of additives can reduce the quantity of categorical coded information because of compositional changes. In terms of concentration, the most important are tartaric, malic, lactic and acetic acids; other acids can be found, whose concentration mainly depends on the fermentation intensity and management (RibéreauGayon et al., 2006b). Tartaric and malic acids are synthesized during the vegetative phase of berry development and accumulate until veraison. During berry maturation, malic acid is used as a carbon source instead of glucose: depending on temperature, its concentration decreases due to cellular respiration (Pereira et al., 2006); during some vinifications, mainly the red wine ones, its transformation into lactic acid by lactic bacteria is required (RibéreauGayon et al., 2006b). In addition, it is possible to achieve similar results through the use of particular yeast strains such as Schizosaccharomyces pombe (Sousa et al., 1991; Loira et al., 2018). In order to increase the malic to lactic acid conversion manageability, these two techniques can be substituted directly adding the malolactic enzyme to the wines or by the use of specific membranes as sustenance (Formisyn et al., 1997; Maicas, 2001).

\section{Nitrogen compounds}

Protein and peptide concentrations in wine greatly differ comparing white to red wines, but also varietal differences are shown (Pocock et al., 2000). In fact, tanning compounds present in red wine precipitate the majority of proteins before bottling (Ribéreau-Gayon et al., 2006c). The foncentration of the latter also varies as a consequence of bentonite treatments (Waters et al., 2005). Pereira et al. (2006) has demonstrated the effect of different bunches exposures (microclimates) on histidine, $\gamma$ aminobutyric acid (GABA), alanine, and arginine concentrations; this proves how the environmental conditions affect amino acid wine profile. Pathogenesis related proteins (PR proteins) is an important protein class because of their technological role in white wines instability (Ferreira et al., 2001). As regards their relative concentration, wines obtained from different geographical areas, varieties and years showed non-dissimilar compositions (Ferreira et al., 2000). In conclusion, unlike the polypeptide composition, both the profile and the amino acid concentration can be important targets for wine fingerprinting.

\section{NEW APPROACHES TO RECOGNISE COMPOSITIONAL PATTERNS: METABOLOMICS AND CHEMOMETRICS}

Metabolomic is the study of the chemical fingerprinting arising by the cellular activity of specific living organisms, such as yeasts or plants. It groups sets of quantitative and qualitative analysis which allow inspecting the composition, in this case, of musts and wines. Through spectroscopic analysis associated with specific chemometrics tools, it is possible to identify patterns statistically correlated to specific samples. Consequently, comparing several wine spectra, it allows exploring the main variability sources, as previously shown for isotopic ratio (Danezis et al., 2016). According to Godelmann et al. (2013) "The information on latent parameters such as grape variety, origin, and vintage is coded in multivariate patterns of multiple parameters in the NMR spectra rather coded in single spectrum markers". It means that three categorical variables of interest, namely variety, geographical origin and vintage, cannot be summarized by the variation of one or a few analytical parameters, but only the combination of a large number of information (multivariate patterns) is able to describe them. This phenomenon is called synergistic effect and can include isotopic data fusion (Monakhova et al., 2014).

Chemometrics is a particular branch of chemistry that applies mathematical and statistical models on analytical data to help in their interpretation; this proves itself very useful especially when the quantity of information exceeds by far the number of categorical variables under investigation. For this purpose, statistical tools, as principal component analysis (PCA), have been developed to allow the elimination of part of the information that is not relevant (spurious information). It is possible to regroup such tools into three categories: exploratory analysis, classification analysis and regression analysis (Medina et al., 2019). During sample characterization in terms of geographical origin, vintage and/or variety, chemometrics tools are used to screen into analytical spectra in search of variability sources linked to these categorical variables.

It is important to distinguish between two approaches. A supervised approach is a process of organizing or 
describing data according to a predefined criterion; an example derives from the linear and multiple regression model: the least square criterion tries to minimize the difference between groups of variables from a regression function. On the contrary, the unsupervised approach requires data to be viewed in their entirety in search of a priori (latent) criterion capable of regrouping them into clusters; this type of approach must be associated with model validation procedures.

\section{TARGET VS. NON-TARGET ANALYSIS}

Compositional analysis on wines and other food matrices can be carried out in two different ways; note that one does not exclude the other and intermediate ways are possible. Profiling and fingerprinting are the two main strategies (Fan et al., 2018). The first one refers to the application of targeted analysis or the determination of the absolute and/or relative concentration of specific chemical species. The second approach involves the application of spectroscopic strategies combined with multivariate statistical methods (chemometrics) without the need for the identification of any the compound. The second one allows investigating information that would not be taken into account through targeted analysis, making the latter a useful approach for investigations in the food sector, especially if used in association with NMR spectroscopy (Godelmann et al., 2013; Christoph et al., 2015; Danezis et al., 2016; Fan et al., 2018). In support of this statement, it has been shown in detail by Godelmann et al. (2013) how to increase the information during exploratory analysis makes it possible to discriminate wine samples more effectively, according to variety and/or geographical origin.

\section{${ }^{1}$ H NMR AND WINE APPLICATIONS}

One of the reasons why nuclear magnetic resonance spectroscopic technology is gaining interest is the sample preparation simplicity, which reduces possibilities of giving rise to errors, and its high analytical reproducibility (Godelmann et al., 2016). The latter is essential for analytical procedures to be implemented at legislative level (Tyagi et al., 2010). The NMR was mainly applied in the past in obtaining high-resolution structural information on a wide range of chemical species and for molecular dynamics studies (Danezis et al., 2016). More recently, the possibility to extract compositional information of water rich sample has extended its application to metabolomic analysis. Furthermore, it is possible to use NMR in association with separation techniques, as liquid chromatography (LC) or capillary electrophoresis (Košir and Kidrič, 2002), for the identification of new chemical species present in wine or in other complex food matrix (Medina et al., 2019).

\section{Nuclear magnetic resonance}

Nucleons (neutrons and/or protons) subjectability to magnetic fields can be explained through the spin presence. Using the NMR technology it is possible to investigate the response of specific atomic nuclei within a magnetic field of known intensity following the application of specific radio frequency (RF) pulse (Farrar and Becker, 1971). The nucleons quantum state, quantifiable by the spin quantum number $(I)$, assumes only $+1 / 2$ and $-1 / 2$ values (Shriver et al., 2014). It is possible to quantify the response only on nuclei which possess a magnetic dipole moment $\mu$ (Equation 4).

$$
\mu=I \gamma \frac{h}{2 \pi}
$$

Eq. 4

where $\gamma$ indicates the gyromagnetic ratio or the magnetic and angular moment particle ratio, $I$ is the nuclear spin quantum number while $h$ is the Planck constant (Farrar and Becker, 1971).

During the ${ }^{1} \mathrm{H}$ NMR experiments, the hydrogen contained in the sample are inserted into a static magnetic field $\left(\mathrm{B}_{0}\right)$ which forces the nuclear magnetic moment to precess around its direction. The frequency characterizing this reorientation it is called Larmor frequency $\left(v=-\gamma \mathrm{H}_{0}\right)$ and it varies proportionally to the applied magnetic field intensity itself (Farrar and Becker, 1971). When the sample is subjected to a second RF pulse oscillating at the same precession frequency and perpendicular to the direction of the static field, it acquires energy, and the precession angle increases according to the intensity $\left(B_{1}\right)$ of the pulse itself; this phenomenon is called resonance. $90^{\circ}$ pulse is defined as an RF pulse the intensity of which is able to rotate the nuclear magnetic moments to the plane perpendicular to the magnetic field (Farrar and Becker, 1971). When the stimulus provided by the radio frequency pulse ceases, the nuclear spins of the hydrogen nuclei tend to return to the original state as relaxation processes occur. The free induction decay (FID) is the graphical representation in time of the transversal magnetization intensity $\left(\mathrm{M}_{1}\right)$ evolution on the plane orthogonal to the external magnetic field $\left(\mathrm{B}_{0}\right)$ direction; through its analysis it is possible to derive or fit two variables: $\mathrm{T}_{1}$ (longitudinal relaxation time) and $\mathrm{T}_{2}$ (transversal relaxation time), which are used to quantify the reacquisition of the initial total magnetization moment $\left(\mathrm{M}_{0}\right)$ and the disappearance of the transversal one (Farrar and Becker, 1971), respectively. The reciprocal quantity of $T_{1}$ and $T_{2}$ are 
defined as spin-latice relaxation rate $\left(1 / \mathrm{T}_{1}\right)$, and spinspin relaxation rate $\left(1 / T_{2}\right)$. Measuring the variation of these two parameters as a function of temperature, frequency and chemical-physical characteristics is used to create molecular interaction models. Relaxometry studies molecular motion into liquids and/or solids also through the $1 / \mathrm{T}_{1,2}$ variation measured at different magnetic fields intensities (Sebastião et al., 2011).

\section{${ }^{1} \mathrm{H}$ NMR in wine characterisation: two strategies}

How is it possible to obtain compositional information, or spectra, about wine samples starting from $\mathrm{T}_{1}$ and $\mathrm{T}_{2}$ determination? The FID shape depends on the composition of the individual signals of transverse magnetization of each hydrogen nucleus present inside the analysed sample: each hydrogen nucleus, within the same molecule, has a single resonance frequency due to other magnetic centres proximity. Through the application of the Fourier transform (Equation 5), it is possible to describe the FID, as a sum of single sine and/or cosine functions (signals) (Farrar and Becker, 1971).

$f(t)=\sum_{n=0}^{\infty} A_{n} \cos \left(\frac{n \pi}{T}\right) t+\sum_{n=1}^{\infty} B_{n} \sin \left(\frac{n \pi}{T}\right) t \quad \mathbf{E q .} 5$

where $T$ indicates the function period. The graphical representation of the signal intensity as a function of the resonance frequencies is the ${ }^{1} \mathrm{H}$ NMR spectrum: in NMR spectroscopy both profiling and fingerprinting approaches are possible (Godelmann et al., 2013).

\section{${ }^{1} H$ NMR profiling}

The targeted approach works after associating spectroscopic peaks with certain previously identified molecules. This is made possible through the addition of an internal standard, tetramethylsilane (TMS), and expressing the distance, also called chemical shift $\left(\delta_{p p m}\right)$, of all other peaks from this last one (Keeler, 2002) - Equation 6.

$$
\delta_{p p m}=\frac{\left(v_{\text {sample }}-v_{T M S}\right)}{v_{T M S}} \cdot 10^{6}
$$

Furthermore, the compounds can be quantified by comparing the amplitude of the curve, at a specific peak, with that of a reference compound of known concentration (Keeler, 2002). This analytical strategy in conjunction with the application of chemometrics tools allowed observing the sources of variability in samples with different geographical origins (Son et al., 2008), variety (Aru et al., 2018) and, in some cases, vintage (Anastasiadi et al., 2009). It is important to stress the possibility to work either directly on wine sample or on dried samples even if in the second case some compositional modifications occur during sample pre-analytical treatment (Aru et al., 2018).

On the other hand, there are cheaper analytical methods to attain comparable results (Danezis et al., 2016) even if both the minimum required intervention on sample preparation, with consequent reduction of analytical time requirements, and the high-throughput information remain interesting (Godelmann et al., 2016). The same author previously demonstrated how, during exploratory chemometrics tools application, the percentage of correct sample-category association benefits from increasing the information quantity (Godelmann et al., 2013).

\section{${ }^{1} H$ NMR fingerprinting}

As it can be seen in Figure 2, minor peaks, to which no compositional information is associated, are present; due to the so called binning procedure, the spectrum is divided into smaller frequency intervals, to proceed calculating the area below the NMR line (Fan et al., 2018). Binning operation is a preanalytical data treatment used to reduce the data quantity. Successively, these areas are used as variables during multivariate statistical analysis (Godelmann et al., 2013), making each spectrum as a unique fingerprint. The information amount thus extracted from each sample is much larger than that obtained with a targeted analysis approach. Therefore, some statistical issues can occur: the increase in number of variables used to classify wine samples could be cause of collinearity problems (Næs and Mevik, 2001); in addition, it is possible to incur in overfitting issues. Both problems can be solved by the application of data mining and/or PCA. Principal component analysis is the most applied statistical tool during NMR spectroscopy because, in addition to solve statistical issues, it permits to regroup sample in a non-guided clustering.

Recently, thanks to fingerprinting approach, many advances in wine classification in terms of vintage, geographical origin, variety, and applied technology have been achieved. The possibility to relate wine terroir, intended as microclimate and soil composition, has been demonstrated (Mazzei et al., 2010). Differences between wines fermented by commercial yeasts strains or autochthonous ones was also shown (Mazzei et al., 2013), indicating another source of data variability. In both projects sample differentiation was obtained, and the greatest sources of data explanation were lactic acid, glycerol, fructose, succinic acid and glucose spectral areas. In 
varietal, vintage, and geographical origin wine characterization both non-targeted and targeted approaches were compared (Godelmann et al., 2013), showing an increasing in correct sample prediction rate in case of whole ${ }^{1} \mathrm{H}$ NMR spectra use. A similar approach showed the possibility to statistically regroup sample from two different vine-growing areas (Italy and Slovenia) (Brescia et al., 2003). These are just examples of ${ }^{1} \mathrm{H}$ NMR applicability to wine; the same approach was used to determine different food matrices characteristics (Esteki et al., 2018) proving this technology's plasticity.

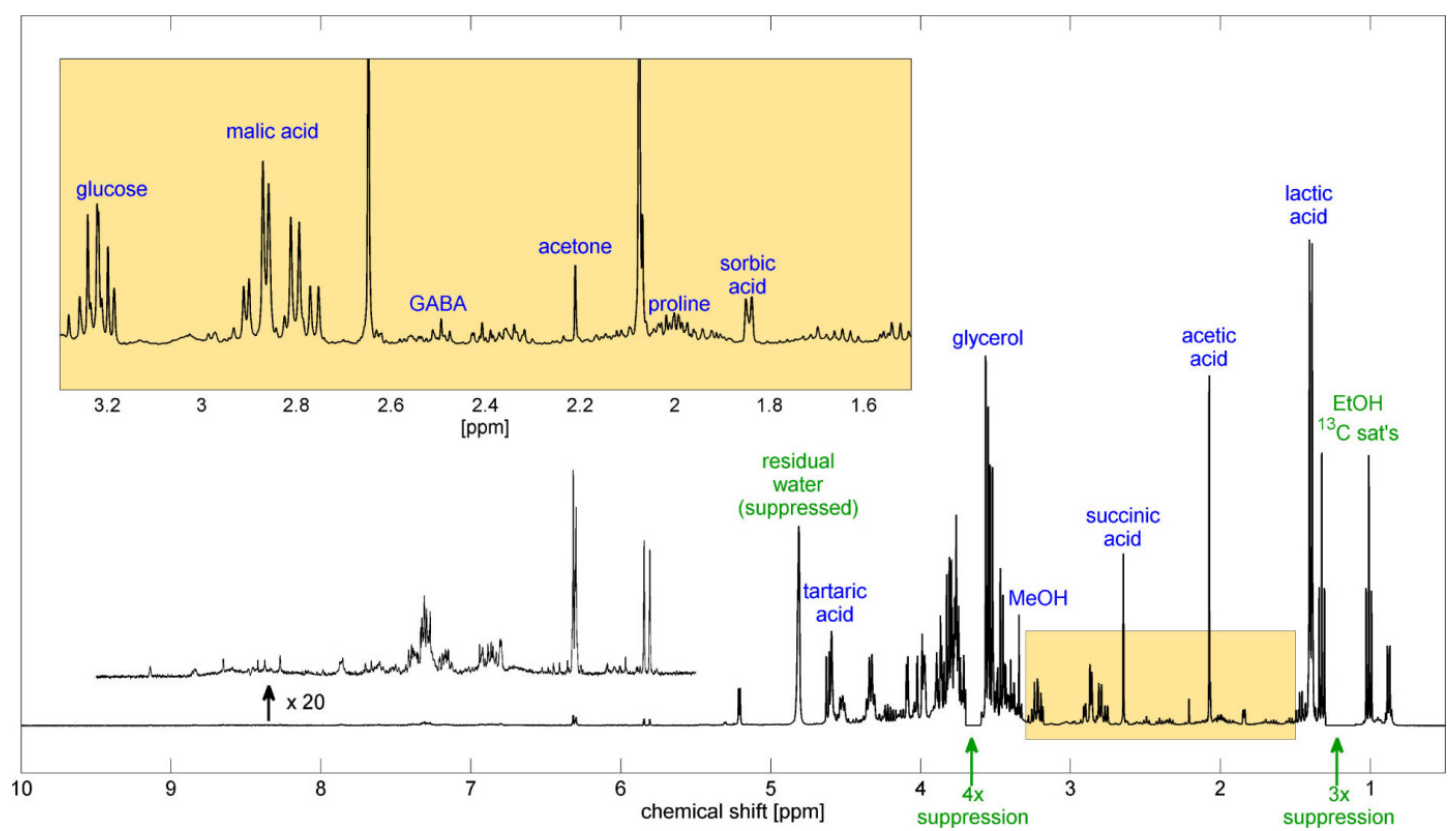

Figure 2. Wine ${ }^{1} \mathrm{H}$ NMR spectrum with some proton line assignments corresponding to underlined molecular groups. The spectrum was obtained at $400 \mathrm{MHz}$, with suppression of eight lines, corresponding to the water and ethanol signals. The wine $\mathrm{pH}$ has been adjusted to 3.10. 3(trimethylsilyl)propionic acid sodium salt (TPS) was added for standard reference. GABA term refers to $\gamma$-aminobutyric acid (Godelmann et al., 2013).

Espectros de ${ }^{1}$ H RMN de vinho com identificação de alguns picos de ressonância associados a moléculas sublinhadas. O espectro foi obtido a $400 \mathrm{MHz}$. Foram suprimidas oito picos, correspondente a sinais de água e de etanol. O pH do vinho foi ajustado a 3,10. Acido 3(trimetilsilil)propiónico sal de sódio (TPS) foi adicionado como referência padrão. O termo GABA refere-se ao ácido $\gamma$-aminobutírico (Godelmann et al., 2013).

\section{CONCLUSIONS}

Different approaches have been described in the categorical classification of wine samples giving greater importance to the information contained in the isotopic ratios and deriving from the chemometrics interpretation of the ${ }^{1} \mathrm{H}$ NMR spectral images. In the first case it was shown how, deeply investigating the isotopic fractionation processes, it was possible to develop an official analytical method to face chaptalisation and/or water addition. In the second case the intent was to stress how the spectral information is able to code for the vintage and the geographical, varietal, technological and compositional characterisation but, due to the high number of environmental factors which impact on fingerprint, the use of chemometrics tools in conjunction with an increase in the amount of available information is required. Some perplexity regarding the a priori samples classification through discriminant analysis (Rodionova et al., 2016) must be clarified. A solution could come from database implementation to increase both compositional and spectral available data. In conclusion, wine is a complex matrix; its composition varies as a function of environmental-genetic expression, technological practices and wine age (Cassino et al., 2019). Therefore, wine classification requires a wide range of knowledge and huge amount of available data. 


\section{ACKNOWLEDGEMENTS}

This work was supported by the Portuguese National Funding Agency for Science and Technology [LEAF (UID/AGR/04129/2020); DL 57/2016/CP1382/CT0025].

\section{REFERENCES}

Anastasiadi M., Zira A., Magiatis P., Haroutounian S., Skaltsounis A., Mikros E., 2009. ${ }^{1} \mathrm{H}$ NMR-based metabolomics for the classification of Greek wines according to variety, region, and vintage. Comparison with HPLC data. J. Agric. Food Chem., 57, $11067-11074$

Aru V., Sørensen K., Khakimov B., Toldam-Andersen T., Balling Engelsen S., 2018. Cool-climate red wines - chemical composition and comparison of two protocols for ${ }^{1} \mathrm{H}-\mathrm{NMR}$ analysis. Molecules, 23, 160 .

Asimov E., 2009. Brunello inquiry cites five wineries. 12 August. The New York Times D, Dining In, Dining Out.

Bautista-Ortín A., Busse-Valverde N., Fernández-Fernández J., Gómez-Plaza E., Gil-Muñoz R., 2016. The extraction kinetics of anthocyanins and proanthocyanidins from grape to wine in three different varieties. OENO One, 50, 91-100.

Bavaresco L., Pezzutto S., Gatti M., Mattivi F., 2007. Role of the variety and some environmental factors on grape stilbenes. Vitis, 46, 57-61.

Bender M., 1971. Variations in the ${ }^{13} \mathrm{C} /{ }^{12} \mathrm{C}$ ratios of plants in relation to the pathway of photosynthetic carbon dioxide fixation. Phytochemistry, 10, 1239-1244.

Bora, D. Donici A., Teodor R., Bunea A., Popescu D., Bunea C., 2018. Elemental profile and ${ }^{207} \mathrm{~Pb} /{ }^{206} \mathrm{~Pb},{ }^{208} \mathrm{~Pb} /{ }^{206} \mathrm{~Pb},{ }^{204} \mathrm{~Pb} /{ }^{206} \mathrm{~Pb}$, ${ }^{87} \mathrm{Sr} /{ }^{86} \mathrm{Sr}$ isotope ratio as fingerprints for geographical traceability of Romanian wines. Not. Bot. Hort. Agrobot. Cluj, 46, 223-239.

Bosso A., Guaita M., Panero L., Borsa D., Follis R., 2009. Influence of two winemaking techniques on polyphenolic composition and color of wines. Am. J. Enol. Vitic., 60, 379-385.

Bréas O., Reniero F., Serrini G., Martin G., Rossmann A., 1994. Isotope ratio mass spectrometry: analysis of wines from different European countries. Rapid Commun. Mass Spectrom., 8, 967-970.

Brescia M., Košir I., Caldarola V., Kidrič J., Sacco A., 2003. Chemometric classification of Apulian and Slovenian wines using ${ }^{1}$ H NMR and ICP-OES together with HPICE data. J. Agric. Food Chem., 51, 21-26.

Canals R., Llaudy M., Valls J., Canals J., Zamora F., 2005. Influence of ethanol concentration on the extraction of color and phenolic compounds from the skin and seeds of Tempranillo grapes at different stages of ripening. J. Agric. Food Chem., 53, 40194025

Cassino C., Tsolakis C., Bonello F., Gianotti V., Osella D., 2019. Wine evolution during bottle aging, studied by ${ }^{1} \mathrm{H}$ NMR spectroscopy and multivariate statistical analysis. Food Sci. Technol. Int., 116, 566-577.

Castellarin S., Pfeiffer A., Sivilotti P., Degan M., Peterlunger E., Di Gaspero G., 2007. Transcriptional regulation of anthocyanin biosynthesis in ripening fruits of grapevine under seasonal water deficit. Plant Cell Environ., 30, 1381-1399.

Catarino S., Curvelo-Garcia A., Sousa R., 2008a. Revisão: Elementos contaminantes nos vinhos. Ciência Tec. Vitiv., 23, 3-19.
Catarino S., Madeira M., Monteiro F., Caldeira I., Bruno de Sousa R., Curvelo-Garcia A., 2018. Mineral composition through soilwine system of Portuguese vineyards and its potential for wine traceability. Beverages, 4, 85

Catarino S., Madeira M., Monteiro F., Rocha F., Curvelo-Garcia A., De Sousa R., 2008b. Effect of bentonite characteristics on the elemental composition of wine. J. Agric. Food Chem., 56, 158165

Catarino S., Trancoso I., Madeira M., Monteiro F., Bruno de Sousa R., Curvelo-Garcia A., 2011. Rare earths data for geographical origin assignment of wine: a Portuguese case study. Bulletin de l'OIV, 84, 333-346.

Cheng J., Liang C., 2012. The variation of mineral profiles from grape juice to monovarietal Cabernet sauvignon wine in the vinification process. J. Food Process. Preserv., 36, 262-266.

Christoph N., Hermann A., Wachter H., 2015. 25 years authentication of wine with stable isotope analysis in the European Union-review and outlook. BIO Web of Conferences, 5, 02020.

Coetzee P., Vanhaecke F., 2005. Classifying wine according to geographical origin via quadrupole based ICP-mass spectrometry measurements of boron isotope ratios. Anal. Bioanal. Chem., $\mathbf{3 8 3}$, 977-984.

Craig H., 1961. Isotopic variations in meteoric waters. Science, 133, 1702-1703.

Danezis G., Tsagkaris A., Brusic V., Georgiou C., 2016. Food authentication: state of the art and prospects. Curr. Opin. Food Sci., 10, 22-31.

Diamond J., 2005. Collapse: How societies choose to fail or fucceed. 173 p. Penguin Books, London, UK

Dinca O.-R., Ursu S., Costinel D., Popescu R., Miricioiu M., Radu G.-L., Popa D., Campeanu C., Elena R., 2015. Samburesti wines characterization in terms of their stable isotope content. U.P.B. Sci. Bull., 77, 176-187.

Dongmann G., Nürnberg H., Förstel H., Wagener K., 1974. On the enrichment of $\mathrm{H}_{2}{ }^{18} \mathrm{O}$ in the leaves of transpiring plants. Rad. and Environm. Biophys., 11, 41-52.

Dunbar J., 1982. A study of the factors affecting the ${ }^{18} \mathrm{O} /{ }^{16} \mathrm{O}$ ratio of the water of wine. Z. Lebensm. Unters. Forsch., 174, 355-359.

English N., Betancourt J., Dean J., Quade J., 2001. Strontium isotopes reveal distant sources of architectural timber in Chaco Canyon, New Mexico. Proc. Natl. Acad. Sci. USA, 98, 1189111896.

Esteki M., Shahsavari Z., Simal-Gandara J., 2018. Use of spectroscopic methods in combination with linear discriminant analysis for authentication of food products. Food Control, 91, $100-112$

Everstine K., Spink J., Kennedy S., 2013. Economically motivated adulteration (EMA) of food: common characteristics of EMA incidents. J. Food Prot., 76, 723-735.

Fan S., Zhong Q., Fauhl-Hassek C., Pfister M.-H., Horn B., Huang Z., 2018. Classification of Chinese wine varieties using ${ }^{1} \mathrm{H}$ NMR spectroscopy combined with multivariate statistical analysis. Food Control, 88, 113-122.

Farquhar G., O’Leary M., Berry J., 1982. On the relationship between carbon isotope discrimination and the intercellular carbon dioxide concentration in leaves. Funct. Plant Biol., 9, 121-137.

Farrar T., Becker E., 1971. Basic concepts in NMR. In: Pulse and Fourier transform NMR: Introduction to theory and methods, 1-8. Academic Press, New York, NY, USA. 
Faure G., Powell J., 1972. The Geochemistry of Rubidium and Strontium. In: Minerals, Rocks and Inorganic Materials. Strontium isotope geology, 1-8. Springer-Verlag. Heidelberg, DE.

Ferrandino A., Carra A., Rolle L., Schneider A., Schubert A., 2012. Profiling of hydroxycinnamoyl tartrates and acylated anthocyanins in the skin of 34 Vitis vinifera genotypes. J. Agric. Food Chem., 60, 4931-4945

Ferreira R., Monteiro S., Piçarra-Pereira M., Tanganho M., Loureiro V., Teixeira A., 2000. Characterization of the proteins from grapes and wines by immunological methods. Am. J. Enol. Vitic., 51, 22-28.

Ferreira R., Piçarra-Pereira M., Monteiro S., Loureiro V., Teixeira A., 2001. The wine proteins. Trends Food Sci. Technol., 12, 230239.

Formisyn P., Vaillant H., Lantreibecq F., Bourgois J., 1997. Development of an enzymatic reactor for initiating malolactic fermentation in wine. Am. J. Enol. Vitic., 48, 345-351.

Geană E.-I., Sandru C., Stanciu V., Ionete R., 2017. Elemental profile and ${ }^{87} \mathrm{Sr} /{ }^{86} \mathrm{Sr}$ isotope ratio as fingerprints for geographical traceability of wines: an approach on Romanian wines. Food Anal. Methods, 10, 63-73.

Gill R., Mayewski P., Nyberg J., Haug G., Peterson L., 2007. Drought and the Maya collapse. Anc. Mesoam., 18, 283-302.

Godelmann R., Fang F., Humpfer E., Schütz B., Bansbach M., Schäfer H., Spraul M., 2013. Targeted and nontargeted wine analysis by ${ }^{1} \mathrm{H}$ NMR spectroscopy combined with multivariate statistical analysis. Differentiation of important parameters: grape variety, geographical origin, year of vintage. J. Agric. Food Chem., 61, 5610-5619.

Godelmann R., Kost C., Patz C.-D., Ristow R., Wachter H., 2016. Quantitation of compounds in wine using ${ }^{1} \mathrm{H}$ NMR spectroscopy: description of the method and collaborative study. J. AOAC Int., 99, 1295-1304.

Haynes M., Lide R., Brun J., 2017. Atomic masses and abundances. In: CRC Handbook of Chemistry and Physics, 1215(1). CRC Press, Boca Raton, FL, USA.

Holmberg L., 2010. Wine fraud. Int. J. Wine Res., 2, 105-113.

OIV, 2019a. Compendium of international methods of wine and must analysis. Vol. 1. International Organisation of Vine and Wine: Paris, France.

OIV, 2019b. Compendium of international methods of wine and must analysis. Vol. 2. International Organisation of Vine and Wine: Paris, France.

Jin Z.-M., He J.-J., Bi H.-Q., Cui X.-Y., Duan C.-Q., 2009. Phenolic compound profiles in berry skins from nine red wine grape cultivars in northwest China. Molecules, 14, 4922-4935.

Kaya A., Bruno de Sousa R., Curvelo-Garcia A., Ricardo-da-Silva J., Catarino S., 2017. Effect of wood aging on wine mineral composition and ${ }^{87} \mathrm{Sr} /{ }^{86} \mathrm{Sr}$ isotopic ratio. J. Agric. Food Chem., 65, 4766-4776.

Keeler J., 2002. NMR and energy levels. In: Understanding NMR spectroscopy, 1-19(2). John Wiley \& Sons, Hoboken, NJ, USA.

Košir I., Kidrič J., 2002. Use of modern nuclear magnetic resonance spectroscopy in wine analysis: determination of minor compounds. Anal. Chim. Acta, 458, 77-84.

Lerno L., Reichwage M., Ponangi R., Hearne L., Block D., Oberholster A., 2015. Effect of cap and overall fermentation temperature on phenolic extraction in Cabernet sauvignon fermentations. Am. J. Enol. Vitic., 66, 444-453.
Loira I., Morata A., Palomero F., González C., Suárez-Lepe J., 2018. Schizosaccharomyces pombe: A promising biotechnology for modulating wine composition. Fermentation, 4, 70 .

Maicas S., 2001. The use of alternative technologies to develop malolactic fermentation in wine. Appl. Microbiol. Biotechnol., 56, $35-39$

Marguerit E., Brendel O., Lebon E., Van Leeuwen C., Ollat N., 2012. Rootstock control of scion transpiration and its acclimation to water deficit are controlled by different genes. New Phytol., 194, 416-429.

Martin G., Danho D., Vallet C., 1991. Natural isotope fractionation in the discrimination of sugar origins. J. Sci. Food Agric, 56, 419434

Martin G., Martin M., Mabon F., Michon M., 1982. Identification of the origin of natural alcohols by natural abundance hydrogen-2 nuclear magnetic resonance. Anal. Chem., 54, 2380-2382.

Martin G., Martin M., Mabon F., Michon M., 1983. A new method for the identification of the origin of ethanols in grain and fruit spirits: high-field quantitative deuterium nuclear magnetic resonance at the natural abundance level. J. Agric. Food Chem., 31 , 311-315.

Martins P., Madeira M., Monteiro F., De Sousa R., Curvelo-Garcia A., Catarino S., 2014. ${ }^{87} \mathrm{Sr} /{ }^{86} \mathrm{Sr}$ ratio in vineyard soils from Portuguese denominations of origin and its potential for origin authentication. J. Int. Sci. Vigne Vin., 48, 21-29.

Mazzei P., Francesca N., Moschetti G., Piccolo A., 2010. NMR spectroscopy evaluation of direct relationship between soils and molecular composition of red wines from Aglianico grapes. Anal. Chim. Acta, 673, 167-172.

Mazzei P., Spaccini R., Francesca N., Moschetti G., Piccolo A. 2013. Metabolomic by ${ }^{1} \mathrm{H}$ NMR spectroscopy differentiates "Fiano di Avellino" white wines obtained with different yeast strains. $J$. Agric. Food Chem., 61, 10816-10822.

Medina B., Augagneur S., Barbaste M., Grousset F., Buat-Ménard P., 2010. Influence of atmospheric pollution on the lead content of wines. Food Addit. Contam., 17, 435-445.

Medina S., Perestrelo R., Silva P., Pereira J., Câmara J., 2019. Current trends and recent advances on food authenticity technologies and chemometric approaches. Trends Food Sci. Technol., 85, 163-176.

Meija J., Coplen T., Berglund M., Brand W., De Bièvre P., Gröning M., Holden N., Irrgeher J., Loss R., Walczyk T., Prohaska T., 2016. Isotopic compositions of the elements 2013 (IUPAC technical Report). Pure Appl. Chem., 88, 293-306.

Meloni G., Swinnen J., 2013. The political economy of European wine regulations. J. Wine Econ., 8, 244-284.

Monakhova Y., Godelmann R., Hermann A., Kuballa T., Cannet C., Schäfer H., Spraul M., Rutledge D., 2014. Synergistic effect of the simultaneous chemometric analysis of ${ }^{1} \mathrm{H}$ NMR spectroscopic and stable isotope (SNIF-NMR, ${ }^{18} \mathrm{O},{ }^{13} \mathrm{C}$ ) data: application to wine analysis. Anal. Chim. Acta, 833, 29-39.

Moreira C., de Pinho M., Curvelo-Garcia A., de Sousa B., Ricardoda-Silva J., Catarino S., 2017. Evaluating nanofiltration effect on wine ${ }^{87} \mathrm{Sr} /{ }^{86} \mathrm{Sr}$ isotopic ratio and the robustness of this geographical fingerprint. S. Afr. J. Enol. Vitic., 38, 82-93.

Næs T., Mevik B.-H., 2001. Understanding the collinearity problem in regression and discriminant analysis. J. Chemometr., 15, 413-426. 
O’Leary M.H., 1978. Heavy atom isotope effects in enzymecatalyzed reactions. In: Transition states of biochemical processes, 285-316. Plenum, New York, NY, USA.

Ogrinc N., Košir I., Kocjančič M., Kidrič J., 2001. Determination of authenticy, regional origin, and vintage of Slovenian wines using a combination of IRMS and SNIF-NMR analyses. J. Agric. Food Chem., 49, 1432-1440.

Paris W., 2002. Top French wine diluted and sold with fake labels. The Observer, 24 February.

Pereira G., Gaudillere J.-P., Pieri P., Hilbert G., Maucourt M., Deborde C., Moing A., Rolin D., 2006. Microclimate influence on mineral and metabolic profiles of grape berries. J. Agric. Food Chem., 54, 6765-6775.

Petrini R., Sansone L., Slejko F., Buccianti A., Marcuzzo P., Tomasi D., 2015. The ${ }^{87} \mathrm{Sr} /{ }^{86} \mathrm{Sr}$ strontium isotopic systematics applied to Glera vineyards: a tracer for the geographical origin of the Prosecco. Food Chem., 170, 138-144.

Pocock K., Hayasaka Y., McCarthy M., Waters E., 2000. Thaumatin-like proteins and chitinases, the haze-forming proteins of wine, accumulate during ripening of grape (Vitis vinifera) berries and drought stress does not affect the final levels per berry at maturity. J. Agric. Food Chem., 48, 1637-1643.

Redan B., Jablonski J., Halverson C., Jaganathan J., Mabud M., Jackson L., 2019. Factors affecting transfer of the heavy metals arsenic, lead, and cadmium from diatomaceous-earth filter aids to alcoholic beverages during laboratory-scale filtration. J. Agric. Food Chem., 67, 2670-2678

Ribéreau-Gayon P., Glories Y., Maujean A., Dubourdieu D., 2006a. Phenolic compounds. In: Handbook of Enology, Volume 2: The Chemistry of Wine-Stabilization and Treatments, 141-203. John Wiley \& Sons, West Sussex, UK.

Ribéreau-Gayon P., Glories Y., Maujean A., Dubourdieu D., 2006b. Organic acids in wine. In: Handbook of Enology, Volume 2: The Chemistry of Wine-Stabilization and Treatments, 3-49. John Wiley \& Sons, West Sussex, UK.

Ribéreau-Gayon P., Glories Y., Maujean A., Dubourdieu D., 2006c. Nitrogen compounds. In: Handbook of Enology, Volume 2: The Chemistry of Wine-Stabilization and Treatments, 109-139. John Wiley \& Sons, West Sussex, UK.

Rodionova O., Titova A., Pomerantsev A., 2016. Discriminant analysis is an inappropriate method of authentication. Trends Anal. Chem., 78, 17-22.

Romano P., Suzzi G., Turbanti L., Polsinelli M., 1994. Acetaldehyde production in Saccharomyces cerevisiae wine yeasts. FEMS Microbiol. Lett., 118, 213-218.

Rossano E., Szilágyi Z., Malorni A., Pocsfalvi G., 2007. Influence of winemaking practices on the concentration of rare earth elements in white wines studied by inductively coupled plasma mass spectrometry. J. Agric. Food Chem., 55, 311-317.
Sacchi K., Bisson L., Adams D., 2005. A review of the effect of winemaking techniques on phenolic extraction in red wines. Am. $J$. Enol. Vitic., 56, 197-206.

Schmidt H.-L., 2003. Fundamentals and systematics of the nonstatistical distributions of isotopes in natural compounds. Sci. Nat., 90, 537-552.

Sebastião P., Gradisek A., Pinto L., Apih T., Godinho M., Vilfan M., 2011. Fast field-cycling NMR relaxometry study of chiral and nonchiral nematic liquid crystals. J. Phys. Chem. B, 115, 14348 14358.

Shriver D., Weller M., Overton T., Rourke J., Armstrong F., 2014 Atomic structure. In: Inorganic Chemistry, 3-33. WH Freeman and Company, New York, NY, USA.

Smith P., McRae J., Bindon K., 2015. Impact of winemaking practices on the concentration and composition of tannins in red wine. Aust. J. Grape Wine Res., 21, 601-614.

Son H.-S., Kim K., Van Den Berg F., Hwang G.-S., Park W.-M., Lee C.-H., Hong Y.-S., 2008. ${ }^{1} \mathrm{H}$ nuclear magnetic resonance-based metabolomic characterization of wines by grape varieties and production areas. J. Agric. Food Chem., 56, 8007-8016.

Sousa M., Teixeira J., Mota M., 1991. Malo-alcoholic fermentation: the influence of operating conditions on the kinetics of deacidification. J. Wine Res., 2, 115-124.

Šuklje K., Lisjak K., Baša Česnik H., Janeš L., Du Toit W. Coetzee Z., Vanzo A., Deloire A., 2012. Classification of grape berries according to diameter and total soluble solids to study the effect of light and temperature on methoxypyrazine, glutathione, and hydroxycinnamate evolution during ripening of Sauvignon blanc (Vitis vinifera L.). J. Agric. Food Chem., 60, 9454-9461.

Tcherkez G., Mahé A., Hodges M., 2011. ${ }^{12} \mathrm{C} /{ }^{13} \mathrm{C}$ fractionations in plant primary metabolism. Trends Plant Sci., 16, 499-506.

Tramontini S., Vitali M., Centioni L., Schubert A., Lovisolo C., 2013. Rootstock control of scion response to water stress in grapevine. Environ. Exp. Bot., 93, 20-26.

Tyagi S., Raghvendra S., Kalra T., Munjal K., 2010. Applications of metabolomics-a systematic study of the unique chemical fingerprints: an overview. Int. J. Pharm. Sci. Rev. Res., 3(1), 8386.

U.S. Food and Drug Administration, 2010. Adulterated food. U.S Food and Drug Administration, Washington, DC, IV. 21, 342-402.

Vorster C., Greeff L., Coetzee P., 2010. The determination of ${ }^{11} \mathrm{~B} /{ }^{10} \mathrm{~B}$ and ${ }^{87} \mathrm{Sr} /{ }^{86} \mathrm{Sr}$ isotope ratios by quadrupole-based ICP-MS for the fingerprinting of South African wine. S. Afr. J. Chem., 63, $207-214$

Waters E., Alexander G., Muhlack R., Pocock K., Colby C., O'Neill B., Høj P., Jones P., 2005. Preventing protein haze in bottled white wine. Aust. J. Grape Wine Res., 11, 215-225. 